UNIVERSITY OF CHITRAL JOURNAL OF LINGUISTICS AND LITERATURE

VOL. 5 | ISSUE I | JAN - JUNE | 2021

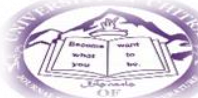

ISSN (E): 2663-1512, ISSN (P): 2617-3611

\title{
Fluid Identity of the Muslim Migrants in America: A Case Study of Hayat Shah in Ayad Akhtar's American Dervish
}

\section{Ghulam Yasin}

Research Scholar in English Literature, University of Sindh, Jamshoro Pakistan ghulam.yasin@scholars.usindh.edu.pk

\section{Dr. Muhammad Saeed Nasir}

Postdoctoral Research Fellow, The School of Language, Literature, Music and Visual Culture, University of Aberdeen, UK $\underline{\text { saeed125nasir@gmail.com }}$

\section{Sadia Rahim}

$\mathrm{PhD}$ Scholar, department of English, women university Multan sadiarahim87@gmail.com

\begin{abstract}
The aim of this research is to deal with the fluid identities of the Muslim migrants settled in America in general and in particular it explores how the conflicts between social and religious values push the protagonist Hayat Shah towards the loss of his personal and religious identity in Ayad Akhtar's novel 'American Dervish' (2012). It describes how the survival in a multicultural society particularly by the Muslim migrants becomes painful. Hayat Shah firstly holds on his remnant tenets of Islamic religion but later he is influenced by the charm of multicultural modern society of America and struggles in sustaining his Muslim identity and finding his new identity for his personal settlement with the surroundings. In this way his identity becomes fluid and keeps on changing. The research concludes that the Muslim migrant Hayat couldn't retain his Muslim identity because he finds his survival only in the adaptation of new, broader, and multicultural settings. This crisis occurs because he has been struck in the issues like religion, mystic philosophy, and cultural conflicts right in his adolescence. It is examined through textual analysis that the journey of Hayat Shah for becoming a Hafiz, and then a Sufi or Dervish comes to an end by availing a new identity of an American. The qualitative research is designed on descriptive analytic method by utilizing the approach of Identity Crisis presented by Eric Erickson.
\end{abstract}

Key Words: religious identity, dervish, Islam, Jewish, migrant

\section{Introduction}

The issue of identity is much debated in the field of literature particularly dealing with the marginalized and multicultural societies. Identity has always been the underlying theme not only 
UNIVERSITY OF CHITRAL JOURNAL OF LINGUISTICS AND LITERATURE VOL. 5 | ISSUE I | JAN - JUNE | 2021

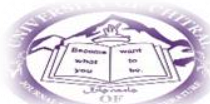

ISSN (E): 2663-1512, ISSN (P): 2617-3611

in the Postcolonial literature but is also the part and parcel of post 09/11 literature. The term 'Identity' is considered a polemic and not easy to define. Now it has become the most discussed term by the scholars of social sciences and humanities in the recent years. It has been the center of debates in every sub-field of Political Science and much work has been done about Identity Politics along with the issues of gender and race. The concept of state identity has opened new horizons in this field at the international scenario but above all the questions of identity on the basis of gender, sexuality, race, nationality, ethnicity and culture have been raised in Political theories on the name of liberalism or vice versa. Identity is "the way individuals and groups define themselves and are defined by others on the basis of race, ethnicity, religion, language, and culture" (Deng, 1995, p. $1)$.

Ayad Akhtar (b. 1970) is a Pakistani-American dramatist, novelist, screenwriter, and an actor. He won the Pulitzer Prize for Drama in 2013 with the presentation of his play 'Disgraced'. American Dervish (2012) is the very first presentation by him and has also been published in more than 20 languages. According to Ali (2015), "it is a message from the author to show to what extent it is so difficult to adhere to one's belief once they find themselves assimilating with other people of different beliefs and suffering because of their own creeds" (p. 85). He mentions that "I think every immigrant community, whether they're defined by their faith or by their national identity, goes through this process of wrestling with what to hold on to and what to leave behind" (web, Aditi Sriram interviews Ayad Akhtar, 2 June 2014).

The fluidity of identity in the study is concerned with the diverse perspectives of identity portrayed in the novel American Dervish (2012). Further these aspects of identity have no welldefined boundaries among them, because "identity is subject to change, modification, reinvention, and even questioning" (Elgezeery, 2015, p. 125). This fluidity reflects almost in every character of the novel because they are endowed with their own fears, subjectivity, settlements, and selfhood while living in the same multi-cultural and multi-ethnic society. However, the study has been delimited to the voice of the protagonist Hayat Shah. The rationale behind it is obvious that Hayat Shah belongs to the Muslim migrant Pakistani family settled in America and his identity is in a continuous flow and flux. It is a supreme issue for him, as he has always been in an incessant quest for his physical and psychological identity throughout the novel. It is not only the journey of his 
UNIVERSITY OF CHITRAL JOURNAL OF LINGUISTICS AND LITERATURE

VOL. 5 | ISSUE I | JAN - JUNE | 2021

ISSN (E): 2663-1512, ISSN (P): 2617-3611

personal identity but later it is concerned with his religion Islam. It later turns into a spiritual journey where he wants to go but he loses everything at the end only to adjust him in the multicultural American society. He only stands as an American not a dervish.

\section{Identity and Fluidity}

Fluidity as narrated by the structuralists is quite different from hybridity because it is "a construct, a hybrid in its many forms and one that is predicated upon a ruse, a performance, a stade" (Phipps, 2003, p. 10). The structuralists do not regard it as the agency of the subject but they consider it as an abstraction. It even may not identify its meaning or subjectivity, though it is an essential element of individuality and subjecthood. Robinson (2007) claims that "human agency leads to a conception of a fluid-yet-fragile self-identity, a conception of community as context of value, and a conception of personal autonomy as situated autonomy" (p. 8). Now this agency makes the identity of some character 'fluid' because no person may have the same characteristics or ideology forever. It always keeps on changing or developing into something new. It may also happen because of the change in living conditions and surroundings where the individuals struggle to exist. The concept of fluid identity emerges "[...] where one's identity is liable to change and is influenced by external factors" (Hongladarom, 2019, p. 2). Robinson (2007) further connects it with the individuals' "[...] identifications with multiple and often conflicting communities" (p. 8). Furthermore, these conflicts develop from the discernments attained by the individuals from the juncture of different cultures and ethnicities.

Further Postmodernists present identity with multiple perspectives that do not contain well defined boundaries. Aaron Balick (2014) relates that postmodern discourse "argues strongly against unitary expressions of self in favour of identities that are multiple, fluid, and decentered" (p. 145). Here "decentered" might not be taken in the light of structuralism where subject is eliminated from the center. Rather, it shows that the subject does not contain a single or central identity that may emphasize as a unitary and characteristic marker. In fact the character possesses multiple identities that depend upon the varied circumstances and different ways of thinking. Grad and Rojo (2008) present this fluidity with the "[...] complexity and context sensitivity of identities" because every character "even within one setting may appeal to a range of identities" (P. 5). In addition, they also argue that "fluidity does not call continuity into question" (p. 10). 
UNIVERSITY OF CHITRAL JOURNAL OF LINGUISTICS AND LITERATURE VOL. 5 | ISSUE I | JAN - JUNE | 2021

Fluidity actually provides the ways of existence those help in adapting the lining of individuals within their cultures and societies.

With the emerging concepts of Globalization, the population of Muslims is increasing rapidly in Europe and America. In the last two decades, the existence of Muslim minority has become much viewable in USA. The Muslims and their religion are being refocused around the world after the tragedy of $9 / 11$. The questions about their religion and identity are being raised, who are they? How is the religion Islam? Why are the Muslims in particular extremists and fundamentalists? There is always a clash between the Islamic culture and all other cultures of the world. It is because this religion of Islam has its own different and separate identity. It cannot be amalgamated in any other culture or religion. If one tries to mix it up, it doesn't work. Such efforts may only result in bring the loss or crisis in identity. So, the Muslims suffer from teething problems wherever they are living in a multicultural or multiethnic society. It becomes difficult to survive with their Muslim identities and even it is harder for them to mix or chose the culture of others.

\section{Theoretical Framework}

Eric Ericson (1968) argues that religious identity provides strength to the ego identity. In other words, religious identity is an essential part of the ego identity. Religious identity emphasizes the process of forming and developing ego or the personality of a person. The implementation of religious affairs in the life of a person plays a vital in developing the identity. It is because religion is the source of providing the most of human beliefs, ideas and ideologies those are further responsible for developing the human personality. According to Erickson, the crisis in identity may occur due the conflicts and clashes striking with the set ideology of a person. The most unsafe age for this loss is the adolescence "A critical period of identity formation, in which individuals overcomes uncertainty, become more self-aware of their strengths and weaknesses" (Buckingham, 2008, p. 2). According to Kroger (2003), when the individuals reach at the age of adolescence,

they have "very little sense of their identity; therefore, they are more prone to accept both positive and negative beliefs in their lives that leads to violent conflict in teenagers" (p. 207).

Moreover, James Marcia (2013) also argues that adolescence consists neither of identity resolution nor of identity confusion in Erickson's proposal, but it is the stage where an individual explores and commits to an identity in the various domains of life including politics, occupation, 
UNIVERSITY OF CHITRAL JOURNAL OF LINGUISTICS AND LITERATURE

VOL. 5 | ISSUE I | JAN - JUNE | 2021

ISSN (E): 2663-1512, ISSN (P): 2617-3611

religion, intimate relationship, friendship, and gender roles and beliefs regarding sexuality. Further it elaborates how a committed individual may come out of the traumatic situation and may change his/her life. It also explains the role of parents and influential persons' decisions, behaviors and actions in constructing or deteriorating the identity of an adolescent because the children are not mature enough to make their future decisions at this stage.

\section{Justification of the Research}

Multicultural and multiethnic groups are found in the society of America. People all around the world migrate to USA for securing the bright future on different grounds. Some people move for their financial wellbeing, some for education, and some with the purpose of living a life full of liberty and comforts. The American Muslim community is considered devoted towards their core religious beliefs and practices and it is a vital part of their identities. In this regard the study explores the issues related to the Muslim immigrants' identity and how they become a separatist on the basis of their religion and culture in a multi-ethnic and multi-cultural American society. Moreover, how the parents are responsible either to form or deteriorate their children identity in a pluralistic society. So, the research would prove very significant to sort out all the reasons and issues which the Muslim migrants face while living in America.

\section{Literature Review}

Ali (2015) presents that the most influential among all the characters is Hayat's mentor Mina. She wants to give him the identity of a hafiz and later as a dervish. His corporal love for Mina also contributes for the downfall of his identity. His relationship with Mina becomes worldlier than the spiritual one. Further Bryson (2012) is the director of Islam and civil society project at the wither spoon institute in Princeton and mentions that the novel 'American Dervish' (2012) deals with the issues being faced by the immigrants and their struggle for survival in a multicultural society. The Muslims' culture is different from all other religions therefore their identities always conflict with the others as well. It is the culture of Muslims to recite the verses in Arabic at the wedding ceremony. When Hayat after memorizing some part of the Quran in English recites some verses in the ceremony. Imam being present in the ceremony asks him to stop recitation in English because it is not being recited in Arabic Language that is directly connected with the religious identity of the Muslims. 
UNIVERSITY OF CHITRAL JOURNAL OF LINGUISTICS AND LITERATURE VOL. 5 | ISSUE I | JAN - JUNE | 2021

ISSN (E): 2663-1512, ISSN (P): 2617-3611

Crosby (2012) observes in her PhD dissertation that "People experience identity through communication, meaning that identity is often framed in terms of enactments or how they express their identity to those around them" (p. 16). Moreover, there are different factors such as religion, culture, country, and community having strong impact upon the identity of anyone. Heike Berner also notices that "Culture, history, and ethnicity are three central and closely intertwined aspects which influence identity formation" (Berner, 2003, p. 11).

Hooti (2011) believes in the importance of identity by saying that "the loss of identity and the quest for it has been the pervasive theme in contemporary American literature" (p. 69). The examples of African American writers are relevant in this regard. Further the writers presenting multicultural American society also pay heed towards this issue. In addition, Bassiri (2010) believes that the American Muslims stand across the boundaries between whiteness and blackness conflicts through their dominant culture. In fact, this standing is between the civilization and primitivism in spite facing many challenges and complications such as Muslim American, "[...] speak out of a poly-religious, poly-ethnic world in a poly-semous tongue, one which we have yet to comprehend" (p. 381).

A Pakistani author Mohsin Hamid has presented the fluid identity of the protagonist Changez in his novel The Reluctant Fundamentalist (2007). Changez has the greater similarities with Hayat Shah and is also stuck in a paradoxical situation in the multicultural society of America like him. Like Hayat, he is also in flux and is desired to fix his fluid identity as an American. They both are Pakistani migrants and Muslims by sect and religion. They both lose their identity because of the pressure they could not absorb in a multicultural American society. They both are young and forget their past identities of being a Pakistani Muslim and are merged in the American society.

Jamal (2006) believes that the novel 'American Dervish' is the depiction of pluralism within Islam, and it also brings forth a serious challenge to "Monolithic Essentialism" that does not provide any guarantee against "silencing the multivocality of the Muslim articulation" (p. 1). In fact, she is of the view that Hayat depicts a difference between the ways of Islam and orders and further also he legalizes the hierarchies between them. So this sort of considerations and ideas bring conflicts in his personality and further crisis in identity. 
UNIVERSITY OF CHITRAL JOURNAL OF LINGUISTICS AND LITERATURE VOL. 5 | ISSUE I | JAN - JUNE | 2021

ISSN (E): 2663-1512, ISSN (P): 2617-3611

\section{Discussion}

According to Chaal (2018) Ayad Akhtar stands against the slogan, "Being a Muslim bought a pain" and tackles the issues faced by the Muslim migrants living in America. In fact, he as an author portrays the lives of American Muslims "literarily, focusing on the Muslims' identity in the West, revealing the Western perspective that associates Islam with hostility and aggression" (p. 14) through his literary works. Further in an interview with Gabriel Green (2013), Akhtar particularly challenges the western discourse after 9/11 that presents the Muslims as "other, which allows the West to justify its political practices and its sense of moral superiority" (Baykara, 2021, p. 142).

The prologue of the novel sets the mood of the author and of the upcoming events. Hayat Shah, the protagonist is much infatuated by the beauty and courtesy of his classmate Rachel, a Jewish girl. They both attend a lecture by Professor Edelstein on the subject title with "Survey of Islamic History in fifteen minutes" conducted by his German fellow regarding the holy book of Muslim. The survey describes that "the bedrock Muslim belief in the Quran as the direct, unchanged, eternal word of God was a fiction" (Akhtar, 2012, 62). Only two Muslim students Ahmed and Sahar are in the lecture with Hayat. They cannot absorb it and quit the class in an anguish mood, but Hayat remains sitting with Rachel. He shows no concern for what is being said about his religion and Quran because he has lost his Muslim identity and is having no concern with it.

The prologue of the novel describes the relationship of Hayat with Rachel a Jewish girl and this relation exists and gets stronger till the epilogue. Simply story between prologue and epilogue is a narration about his mentor Mina, Hayat is a narrator and Rachel is a listener. Rachel asks Hayat to recount the story and he is stunned at this request: “I didn't move. The fact was, I didn't want to leave. I wanted to stay. I wanted to tell her" (Akhtar, 2012, 132). If Rachel does not ask Hayat to recount the story of Mina; there would have been no American Dervish at all.

American Dervish (2012) in particular deals with the fluid identity of Hayat Shah, an American belonging to a Pakistani migrant family. He is living with his father Naveed Shah and his mother Muneer in Milwaukee. Naveed Shah belongs to the first generation migrant and is having no concern with his religion. He always tries to adjust himself according to a new culture and wants to live the life of ease. He loves to adjust his identity according to the new social 
UNIVERSITY OF CHITRAL JOURNAL OF LINGUISTICS AND LITERATURE VOL. 5 | ISSUE I | JAN - JUNE | 2021

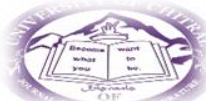

ISSN (E): 2663-1512, ISSN (P): 2617-3611

conditions and requirements. The mother Muneer also shows no concerns with Islam and even is more attracted towards the Jewish philosophy. Mina Ali, another migratory from Pakistan after being divorced by her husband, is the tutor of Holy Quran and also teaches the basics of Islam to Hayat.

Hayat Shah being only a teenager is always influenced by the different philosophies being followed by the other characters around him. Ali (2015) argues that "identity is not fixed and singular. It is fluid, multiple, relational and in process" (p. 80). Similarly his identity also becomes fluid and keeps on changing because he has been struck in the complex issues like of religion, mystic philosophy and cultural conflicts. Importantly there is no one to hold his hand strongly and guide him. So he fights as an individual and wants to discover himself "not only as a man, but as an American" (Akhtar, 2012, p. 295). His fault is that he wants to survive in the multi-cultural society of America with his Muslim identity that makes him a separatist. Zaffar (2020) also argues, "This struggle for assimilation in America generates an internalized crisis of identity which creates a fracture in their hybrid existence" (p. 1).

On the issue of religion, there exists a great conflict in the Asian and multi-ethnic American societies. In Asia, religion is an emotional element in the lives of people whereas it only a private affair of an individual in America. Second Hayat has not learnt religion Islam by any religious scholar, only a female tutor is the source of his learning. Further the real practices of his religion Islam are contrary to the traditions and norms of a multicultural society where he is living. So, this conflict in the religious and social practices is the real cause of his identity crisis. As Huang (2010) argues that "religion can play an important role in defining a person's identity" (p. 31). Further Moody (2019) also illustrates that "The connection between religion, ethics, and the surrounding social world is one that seems unavoidable" (p. 25).

Hayat Shah also could not learn the religion at home because of his parents' lack of interest in religion though they both are the Muslims by faith. His father is the character with a secularmind set and never likes to be limited within the norms of a religion. "Hayat's father, Naveed, is a secular neurologist who thinks religion is for fools" (Akhtar, 2012, 320). His mother not only ignores the religious beliefs and practices but even she is more inclined towards the Jewish people. The family environment of Hayat Shah may be understood that they are a Muslims family living 
UNIVERSITY OF CHITRAL JOURNAL OF LINGUISTICS AND LITERATURE VOL. 5 | ISSUE I | JAN - JUNE | 2021

in America. At one side, they are living as Muslim and have maintained their Muslim identity apparently. However, in contrast they are awestruck by the charm of multicultural and social conditions "His father and mother teach him to respect Jewish. Yet, he finds some contradictions in reality" (Handayani, 2020, p. 54).

Hayat wants to attain the identity of a Hafiz-e-Quran because he considers his father a sinner and wants to save him from the wrath of God and torture in the Hellfire. His mentor Mina tells him "every hafiz earned not only his own place in Paradise, but his parents' as well. No matter how many drinks, no matter how many mistresses, Father would be saved" (Akhtar, 2012, p. 153). Later this desire persuades him of coming closer to the God and becoming a Sufi. Though he does not know anything about it and begins to learn the philosophy of Sufism again by his mentor Mina. He requests Allah almighty not to leave his father to be burnt and tortured in the Hell-fire as the result of his disbeliefs and sinful life. "I saw Father waving at me through the endless flames. I begged God to forgive him, to turn him away from his sins. I heard Father's cries of pain as the fires burned him" (Akhtar, 2012, p. 320).

Mina persuades him for becoming a Sufi or Dervish because symbolically she is a Sufi in her own self who bears all the sufferings in life with patience. She never seems complaining about the ill-deeds committed against her by her husband. She is the best choice to teach Hayat Shah for how to become a dervish. This struggle brings a conflict in the life of a young boy either he is to become only a dervish or an American dervish. She wants to teach him that life, death, pleasure, grief, palaces or prisons are all equal in the eyes of a Dervish because he meditates nothing but the pathway to reach closer to God; "It's about finding God now. In the everyday. Here. With you. That's what the Sufis teach" (Akhtar, 2012, p. 342).

Mina narrates him the story of a dervish who abandons the worldly pleasures for the sake of Allah. He may attain the rank of a higher Muslim with this identity because the dervish struggles to attain redemption and insight through humility rather than pride in being chosen by Allah. Moreover Hayat Shah compares the status of the chosen class of America with the typical exclusive class of minority working there and he finds a great gulf between the two. He also mistaken the word 'dervish' as 'gurvish' that reminds him of the school caretaker Mr. Gurvitz, sprawling a trash-cane on the wheels and representing the American waged folks. He thinks to 
UNIVERSITY OF CHITRAL JOURNAL OF LINGUISTICS AND LITERATURE VOL. 5 | ISSUE I | JAN - JUNE | 2021

deal with the gap separating him and Mr. Gurvitz, without questioning the hierarchy of this class. It represents two different classes and identities. Secondly Hayat considers him inferior to Mr. Gurvitz because of his American identity and working status and also does not find any reason of being superior to him on the basis of color, origin, and creed. So this sort of conflict in ideas contributes in developing the complexes and disorder in the personality of Hayat Shah.

American Dervish (2012) is in fact a mirror reflecting the community of the emigrants settled in America. Though Mina is the tutor of Quran but she also wants to integrate herself as per demands of the American society. She changes her lifestyle to sustain the American identity which is to connect the opposite poles "Her fashionable hairstyle made her a modern woman, an American woman" (Akhtar, 2012, p. 69). The relation of Hayat with his tutor of Quran now does not remain only a spiritual but corporal also, "[...] adolescents must undergo a 'crisis' in which they address key questions about their values and ideals, their future occupation or career, and their sexual identity" (Buckingham, 2008, p. 2). Further he becomes more interested in her body when once he looks her nude body during taking a shower-bath. Later Mina shows love for the young boy and advises him by taking in her arms, "She took me into her arms, and all at once I felt it again: that exquisite shudder running along my limbs, up my back" (Akhtar, 2012, p. 42). This sort of loving piece of advice is a mix up of both physical and religious motives. Mina wants to look him a hafiz or a Dervish but he is now much attracted towards her physical appearance. So, the relationship between the tutor and a Hafiz pushes him towards a new identity of a young lover.

Moreover, the influence of a mother and the relationship of Hayat with a Jewish girl Rachel also influence his Muslim identity. He is dejected regarding his identity and finds it nowhere. He comes in the arms of a Jew Rachel to find solace. She is a game changer and tries to get him merged in the mixed American culture. Second the bent of his mother towards Jewish also influences his personality. Her mother is desired to look Hayat like the Jews, "That's why I'm bringing you up so differently [...] the fact that Nathan's Jewish is good thing. They understand how to respect women" (Akhtar, 2012, p. 117). Hayat takes it solemnly to grow the affectionate relations with Rachel and feels free while living within her concerns. His brought up under the influence of Jewish thought and his dealings with Rachel drag him towards a new American 
UNIVERSITY OF CHITRAL JOURNAL OF LINGUISTICS AND LITERATURE VOL. 5 | ISSUE I | JAN - JUNE | 2021

ISSN (E): 2663-1512, ISSN (P): 2617-3611

identity. He realizes himself having a romantic soul and spirit; "It was in Rachel's arms - and it was with her love - that I finally discovered myself not only as a man, but as an American" (Akhtar, 2012 , p. 345). Now he has lost all his past real identity attached with Islam and feels comforts in the company of a Jewish girl as an American.

Finally, the relationship of Hayat with Islam becomes ordinary, and he feels nothing different when he goes for prayers. No longer he means Islam anything and says, "my heart yearned to pray. I put my hands out before me in the Muslim style and tried to conjure the heartfelt fire I knew so well from back when Mina lived with us. But my words rang hollow. Like sounds spoken to the deaf, or worse, to no one at all" (Akhtar, 2012, p. 333). Things become worse day by day and before the epilogue, Hayat wanted to talk to Mina and to announce his loss of Muslim identity or giving up of his religion practically: "I wanted to tell her [Mina] that I had been giving up on Islam little by little for years and that now there was barely anything left" (Akhtar, 2012, p. 325). His desires to attain the identity of a Hafiz and his relationship with the holy Quran have also been lost. Hayat simply says that he has just superficially touched the Holy Quran for the last ten years or so and has denied all the respect once he had for the religion. "I didn't kiss the cover as I usually did. I just put the Quran down on top of the other books [...] It was the last Quran I would touch for almost ten years" (Akhtar, 2012, p. 157).

Based on several reasons, Hayat Shah could not become an American dervish. Firstly, he abandons all the Islamic values and teachings. He begins to trace out his identity with the Jews, particularly Rachel after negating the Islamic values. His relationship with Islam and its followers becomes weaker right after the death of his mentor Mina. Secondly, Hayat loses his identity of Dervish because of the failure of his dream. Now his dream is not with the Prophet during his prayers. "Mina had said it was a great blessing to see the Prophet in a dream, but there didn't seem to be any blessing in mine. Instead of staying and praying with him, I'd left" (Akhtar, 2012, p. 229). Thirdly, the father-son relationship also keeps him away from becoming the American Dervish. He always considers his father a sinner moving towards the eternal hell. Even he begins to keep an eye on the private affairs of his father. Such torn relationships don't provide him relief in the daily life. 
UNIVERSITY OF CHITRAL JOURNAL OF LINGUISTICS AND LITERATURE VOL. 5 | ISSUE I | JAN - JUNE | 2021

ISSN (E): 2663-1512, ISSN (P): 2617-3611

On the other hand, Hayat Shah also could not attain the identity of a Hafiz due to some certain reasons. First, his tutor Mina convinces him to learn Quran in English with the view that all the deeds of a man are based upon his intentions, not in appearances. Then Souhef, the Imam, develops a conflict and counters this point of view by telling Hayat "you have to learn the holy book in our holy language for that. But don't be discouraged. You have all the time in the world" (Akhtar, 2012, p. 301).

Second, the relationship of Hayat with his mentor Mina converts from spiritual to corporal. This physical attachment further becomes stronger when Hayat gets a chance to eye upon her naked body when she is taking bath. This naked image of her body becomes a turning point for his identity. "The image I thought I'd taught myself to forget would return, unbidden — her breasts; [ .. I I made fresh attempts to suppress the mental picture. To no avail. The more I resisted, the more persistent it proved" (Akhtar, 2012, p. 161).Third, Hayat is somehow a mother fixated child. He is much closer to his mother than to his father. Both his parents are much farther away from their Islamic religion. It seems that his father has no belief in religion and mother is more inclined towards Jews. In this way his mother's bent towards the Jewish people also affects his religious identity.

The struggle of Hayat Shah in more than one identity like Muslim Identity (Hafiz and Dervish), national identity (American), Lover (Mina and Rachel) and importantly his conflicts with parents indicate his identity crisis as well as hybridity described by Homi. K. Bhabha. This fluid identity brings people to rotate in the "in-between spaces of cultures called as third space by Bhabha" (Baykara, 2021, p. 141).

\section{Conclusion}

The novel American Dervish (2012) revolves around the protagonist, Hayat Shah. He is basically a teen age boy who lives with his Pakistani migrated family in Milwaukee's rural area. The settings of the novel present the conditions of America in the era of 1980s. Since the identity is not fixed or single in its nature but it is fluid, dynamic and multi-dimensional. Everyone is appropriate and suitable for the 'fluidity' and 'multiplicity' of one's own identity. The loss and fluidity of identity have been the prevalent themes in the novel. The author Ayad Akhtar successfully conveys a message through Hayat Shah that it is almost impossible to survive as an individual and containing individual belief and ideology in multicultural societies like of America. 
UNIVERSITY OF CHITRAL JOURNAL OF LINGUISTICS AND LITERATURE

VOL. 5 | ISSUE I | JAN - JUNE | 2021

ISSN (E): 2663-1512, ISSN (P): 2617-3611

Ayad Akhtar has dexterously presented one of the well-wrought American novels. He becomes representative of the Muslim migrants living in the western and American multicultural societies. He has vividly presented the problems they face there through Hayat Shah. Hayat has not only lost his religious identity rather he has also started some resistance against his religion Islam. Once the resistance has been shown against the multicultural and multiethnic American society through the rigid behaviors of the Muslim community as a whole, later the identity of Hayat Shah is shattered as an individual and he begins to resist the tenets of Islam which he practices earlier. In this resistance, his journey towards becoming a Muslim Dervish ends with the identity of an American Dervish.

Secondly Hayat Shah is young enough and influenced by different mature characters like his mentor, Mina who wants to see his identity as Hafiz and later as a Dervish, his mother wants to grow him up like the Jews, his father wants to see him an American. After being influenced by the American culture and religious behaviors of other characters he loses all his religious Muslim identities like of a Hafiz and a Dervish and becomes closer to his only identity of an American.

\section{References}

Akhtar, A. (2012). American Dervish: Weidenfeld \& Nicolson: Orion Publishing Group Ltd.

Ali, R. S. (2015). Loss of Identity in Ayad Akhtar's American Dervish. International Journal of Literature and Arts, 80-87.

Balick, A. (2014). The Psychodynamics of Social Networking: Connected-up Instantaneous Culture and the Self. London: Karnac Books Ltd.

Bassiri, K. G. (2010). A History of Islam in America. Cambridge: Cambridge University Press, 133, 98.

Baykara, T. and Kaçmaz, E. (2021). In or Between the Cultures: Hybridity in American Dervish. Söylem Filoloji Dergisi, 6 (1), 139-148. https://doi.org/10.29110/soylemdergi.881481 n

Berner, H. (2003). Home Is Where the Heart Is? Identity and Belonging in Asian American Literature. Bochum: Ruhr-University Bochum. 
UNIVERSITY OF CHITRAL JOURNAL OF LINGUISTICS AND LITERATURE

VOL. 5 | ISSUE I | JAN - JUNE | 2021

ISSN (E): 2663-1512, ISSN (P): 2617-3611

Bryson, J. (2012). Faith Confronts Culture in “American Dervish". Retrieved from https://contendingmodernities.nd.edu/authority-community-identity/faith-confrontsculture-in-american-dervish/

Buckingham, D. (2008). Introducing Identity. Youth, Identity, and Digital Media. Cambridge: The MIT Press.

Chaal, H. (2018). The Muslims' Identity in American Society Through Ayad Akhtar's Play The Who and the What. English Language Literature \& Culture, 3 (1), 14-19. doi: https://doi.org/10.11648/j.ellc.20180301.13

Crosby, E. M. (2012). Exploring Stigma, Identity Gaps, and Consumption. Urbana: Illinois at Urbana-Champaign.

Daley, D. (2012). Plot contrivances whirl in American Dervish. America: USA Today Review.

Deng, F. M. (1995). War of Visions: Conflict of identities in Sudan. Washington: Brookings.

Elgezeery, G. (2015). Fluid Identity of the Daughter in Jackie Kay's the Adoption Papers. International Journal of Applied Linguistics \& English Literature, 125-136.

Erikson, E. H. (1968). Identity, youth and crisis. London: Faber \& Faber.

Grad, H., and Rojo, L.M. (2008). Identities in Discourse: An Integrative View. In Rosana Dolón and Júlia Todolí (Eds.), Analysing Identities in Discourse. Amsterdam and Philadelphia: John Benjamins Publishing Company, 03-28.

Hamid, M. (2007). The reluctant fundamentalist. Toronto: Bond Street Books.

Handayani, R. (2020). Being Muslim Immigrants in America: Preservation, Resistance, and Negotiation of Identity in Ayad Akhtar's “American Dervish. Vivid: Journal of Language and Literature, 9(2), 51-56.

Hongladarom, S. (2019). Fluid Identity, Freedom and Responsibility. Retrieved from researchgate.net: https://www.researchgate.net/publication/334507210

Hooti, N. (2011). The Quest for Identity in Arthur Miller's the crucible. Journal of English and Literature, 68-74.

Huang, S.-Y. (2010). The Dialogism of Self and Other in Contemporary American Drama. . Louisiana: Diss. Louisiana State University. 
UNIVERSITY OF CHITRAL JOURNAL OF LINGUISTICS AND LITERATURE

VOL. 5 | ISSUE I | JAN - JUNE | 2021

ISSN (E): 2663-1512, ISSN (P): 2617-3611

Interview with Ayad Akhtar, AN. ACT: A Contemporary Theatre. "A Conversation between Playwright Ayad Akhtar and Anita Montgomery" http://www.acttheatre.org/Downloads/AyadAkhtarInterview.pdf

Ismail, S. M. (2017). Between the Sacred and the Secular: The Process of Assimilation in Ayad Akhtar's American Dervish. Language in India, 17 (11), 51-60.

Jamal, M. (2006). Sufism in the West. (J. M. Hinnells, Ed.) Routledge: New York, 1-27.

Kroger, J. (2003). Identity Development during Adolescence. Blackwell Handbook of Adolescence, 204-226.

Marcia, J., and Josselson, R. (2013). Eriksonian Personality Research and Its Implications for Psychotherapy. Journal of Personality, 81(6), pp. 617-629. https://doi.org/10.1111/jopy.12014

Moody, L. I. (2019). Religion and Realism in Late Nineteenth Century American Literature. . Louisiana: Louisiana State University.

Phipps, A. (2003). Languages, Identities, Agencies: Intercultural Lessons from Harry Potter. Language and Intercultural Communication, 3(1), 6-19.

Robinson, A. M. (2007). Multiculturalism and the Foundations of Meaningful Life: Reconciling Autonomy, Identity, and Community. Toronto: UBC Press.

Ullah, K. (2020). Problematics \& Process of Pakistani Diasporic Identity in Sidhwa's An American Brat (1993). Journal Of Religious Studies, 3(1), 145-171.

Zafar, S. (2020). South Asian Muslim Americans as Model Minorities: Conflicted Identities in Mohsin Hamid and Ayad Akhtar. University of Waterloo, Canada. http://hdl.handle.net/10012/16200

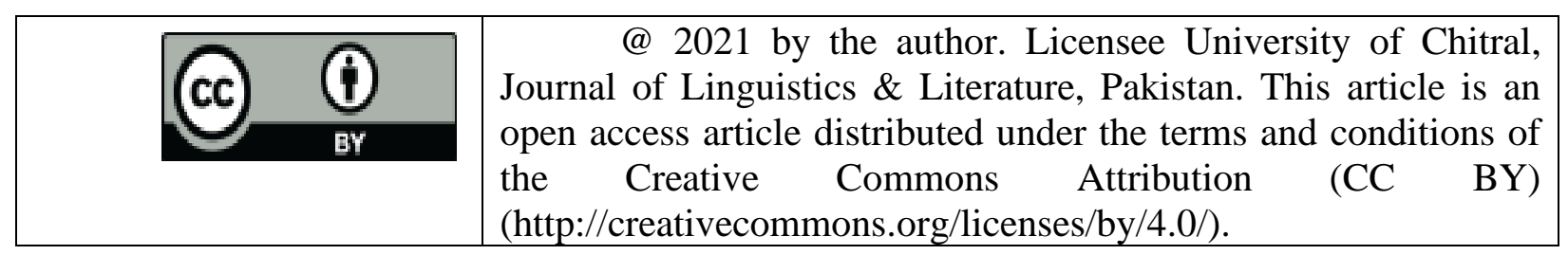

